\title{
Fiqih Ibadah Competence Model Developments Through Jurisprudential Inquiry Model Based on Local Wisdom in Students' Learning
}

\author{
$1^{\text {st }}$ Eri Sakti \\ Dep. of Ilmu Agama Islam, \\ Faculty of Social Science, \\ Universitas Negeri Padang, Padang, \\ Indonesia
}

\author{
$2^{\text {nd }}$ Fuady Anwar \\ Dep. of Politics and Social Sciences, \\ Faculty of Social Science, \\ Universitas Negeri Padang, Padang, \\ Indonesia, \\ $3^{\text {rd }}$ Akmal \\ Dep. of Politics and Social Sciences, \\ Faculty of Social Science, \\ Universitas Negeri Padang, Padang, \\ Indonesia, \\ akmal.pkn@fis.unp.ac.id
}

\begin{abstract}
The purpose of this study are: (1) to find out the results of the problem analysis of the implementation of lecture competency learning in Fiqh in the subject of the Universitas Negeri Padang (UNP) Islamic Studies Program-Ilmi Agama Islam (IAI) in Social Science Faculty-Fakultas IlmuSosial (FIS) as a basis for increasing Islamic legal competence for students, for effective and appropriate learning models to improve the quality of learning with Jurisprudential Inquiry (Legal Review); (2) developing Juris prudential Inquiry learning model in the IAI field; (3) producing islamic science learning and teaching materials that are in accordance with the applicable curriculum, and for research purposes (4) is analyzing the validity and affordability Ibadah Jurisprudence competency learning models and teaching materials as the model development result, as well as a quality learning model involving all undergraduate students of IAI FIS UNP. This research uses the $R \& D$ (research and development) approach. The research
\end{abstract}

\section{INTRODUCTION}

The fundamental problem of islamic religious sciences students of FIS UNP is the understanding of learning of Figh ibadah in the IAI FIS UNP course, such as lack of Islamic procedure used design and development research. It is hoped that this research can produce an effective and appropriate learning model in improving the competence of the field expertise fiqh, so that students as future leaders of the nation and state have an awareness of Islamic Jurisprudence. Students are hoped to be able to think cross-sectoral and to love their religion, nation and country. As intellectuals who think conceptually, be able to show the identity of Islam and the nation in social relations. This research is also expected to produce teaching materials that can be used in accordance with IAI curriculum standards. The findings in this study are: 1) learning competence Fiqh Ibadah can be improved through under standing based on local culture; 2) for the learning method through jurisprudential inquiry, students' understanding can be increased through completing cases using a variety of learning about islamiclaw.

Keywords-Local Wisdom, Fiqih Ibadah, Jurisprudential Inquiry

legal insights, integral comprehensive thinking, a sense of obedience, understanding religious symbols especially aqeedah, shari'ah, and morality, a sense of nationality, love and good communication skills. [1] states that the demands of graduates from all starata are and 
will continue to face challenges in an increasingly tight and complex workforce competition. The world of work will objectively demand professional human resources, and not be uprooted from the roots of their own people.

Azra [2] said that the goal of learning Islamic law, morality as in the IAI Study Program that had not been achieved in the curriculum was to become a human being that could carry out the life of the nation and state. Especially in Islamic civil law. For this reason, the fundamental problem of students is the learning method error, which is using the Jurisprudential Inquiry method to build students' Islamic legal awareness abilities. The application of this method in the learning process of Fiqh of ibadah is very important to improve the ability of students in good education and comprehensive/ cross-sectoral thinking in making decisions as a constructive learning [3].
The results of problem analysis mapping: (1) the implementation of Fiqh Ibadah learning, as a basis for increasing competence, for effective and appropriate learning models improve the quality of learning with Jurisprodential Inquiry; (2) developing a model for learning Jurisprudential Inquiry in the field of Fiqh Ibadah; (3) producing teaching materials of Fiqh Ibadah in accordance with the applicable curriculum; and (4) testing the validity and rigor of the models and teaching materials for competence in Figh Ibadah results model development at the IAI FIS Study Program.

The reality in the field shows that the students' results have not fulfilled expectations such as: (1) lacking the principle of obedience, inconsistency in uncovering or solving problems that arise in society and nation, (2) often prejudice, without being supported by the argument and the data taking the decision of Fiqh Ibadah.

Tabel 1. Students' Fiqh Ibadah Awareness Reality

\begin{tabular}{ccccc}
\hline \multirow{2}{*}{ No } & Students' Group & \multicolumn{3}{c}{ Students' Competence Degree } \\
\cline { 3 - 5 } & & Knowledge & Skills & Attitude \\
$\mathbf{1}$ & Batch I 20 Students & $46 \%$ & $39 \%$ & $51 \%$ \\
$\mathbf{2}$ & Batch II 19 Students & $37 \%$ & $49 \%$ & $45 \%$ \\
$\mathbf{3}$ & Batch III 16 Students & $55 \%$ & $53 \%$ & $58 \%$ \\
\hline Source: Data IAI FIS UNP, 2018
\end{tabular}

The formulation of the problem in this research consist of three: (1) how is the competence of Fiqh Ibadah of IAI FIS UNP students in learning in IAI FIS UNP Study Program?; (2) how is the effectiveness of the Jurisprudential Inquiry learning model in learning Fiqh Ibadah at IAI FIS UNP Study Program?, (3) Research Objectives, Outputs, and Contributions ?.in detail, the research objectives are: (1) to analyze the competence of Fiqh Ibadah of IAI FIS UNP students in learning at IAI Study Program FIS UNP; (2) to find the Jurisprudential Inquiry learning model in learning Fiqh Ibadah at the IAI Study Program FIS UNP.

Learning Islamic Fiqh as its main competence demands the ability of students to comprehend aqeedah, sharia, and morality as a whole in a regulation of the life of a Muslim. The main aim of learning the Fiqh Ibadah is to provide knowledge about the concepts of Islamic law, theories of Islamic civilization, and the implementation of theories in the national civil law in Indonesia.

The history of the nation of Indonesia shows that the application of fiqh Ibadah in the form of Islamic civil law has occurred through various legislation, such as pilgrimage, waqf, zakat, religious court for marriage, economic activity. The Fiqh Ibadah is directed at how to prepare citizens who are: able to develop their potential to have spiritual power, self-control of personality, intelligence, moral character, and the skills needed by themselves, society, nation and state (mandated by Law No. 20 of 2003). According to Azra [2] that in an effort to 
develop the curriculum of the Fiqh Ibadah in the curriculum there are a number of things that need to be reviewed including:

1) the extent to which the topics in the curriculum are relevant to the Islamic spirit, take advantage of the momentum of reform.

2) studying which material can be issued, combined and streamlined and which is absolutely essential for the subject of students.

3) the methodology for delivery is changed from doctrinaire toward democratic.

The hard task facing the teaching of Fiqh Ibadah is to change the character of the nation's generation of citizens towards consistent and consistent principles in carrying out Islamic law. According to thinker Moore [4] there are 5 patterns of community response to the success of building the nation's character going forward: (1) conformity (acceptance) which is accepting; (2) innovation (innovative) which is accepting and practicing in attitudes and actions to achieve it; (3) ritualism (rhythmic), i.e. rejecting cultural goals but adhering to ways that have been institutionalized in Islam; (4) retreats (turning), i.e. rejecting or leaving both good deviant and heretical teachings reaching it; and (5) rebellion, namely rejecting goals that are not in accordance with the Koran, Hadith, Ijma and qiyas. To overcome these problems, an effort should be made to implement a learning model towards quality learning [5].

\section{Jurisprodential Inquiry Learning Model}

Learning with the Jurisprodential Inquiry (JI) model or also called the Legal Study method emphasizes that students obey the principle, consistent in making decisions where the advantages of this method are: the success of this model is through the Socratic dialogue method (confrontational debate) as quoted by [5]. Steps to be taken include: (1) orientation of the case, (2) identifying the issue, (3) taking a position (attitude), (4) exploring the arguments to support the position (attitude) that has been taken, (5) clarifying and strengthen position (attitude), and (6) test assumptions about facts, definitions and consequences.

Improving learning is done by implementing a learning model based on Jurisprodential Inquiry (Legal Study) with the approach to the Piqih Ibadah case. In this case learning is designed by finding solutions using legal-based arguments, theories, concepts that are believed to be the proof. Why do they stand firm in the opinions or stand of students after considering a variety of arguments and strong arguments. The application of the Jurisprodential Inquires method in the process of learning Fiqh Ibadah is very important to improve the ability of cognition and change student affection into principles, build selfreliance, think logically. As a constructive learning environment, Jurisprodential Inquiry provides learning in real situations based on cases that occur for students so that they can produce permanent knowledge [5].

The Jurisprodential Inquiry Procedure developed by [6] that in general the main key to the success of this model is through the Socratic dialogue method (confrontational debate). Steps that must be taken include: (1) orientation to the case, (2) identifying the issue, (3) taking the position (attitude) based on the argument, (4) exploring the argumentation to support the position (attitude) that has been taken, (5) clarify and strengthen the position (attitude), and (6) test assumptions about the proposition, definition, and consequences.

\section{METHOD}

The research method used is Research and Development or R\&D. According to Sugiyono [7] revealed that development research in education is an industry-based development model in which the findings of research are used to design new products and procedures, which then systematically field-tested, evaluated, and refined until they meet the 
specified criteria if effectiveness, quality, or similar standards. The competency data Ibadah Fiqh for students of IAI FIS UNP was obtained from questionnaires that were distributed to 40 IAI students. The results of the data obtained were analyzed in two indicators namely pegagogic competence and professional competence of IAI students. The findings were explained as follows.

This research development was carried out to develop products in the form of learning models of Fiqh Ibadah. The model component is focused on learning methods and strategies. The reason for the development of this model is because the learning of jurisprudence on the subject matter competence in the subject of IAI for all students. In an effort to develop a learning model and test the effectiveness of the learning model that has been developed, this research will be carried out in 3 stages, namely the descriptive research stage, the development and testing / validation of the model. To test product quality theoretically (expert test), small group test, and large group trial. To capture information from various sources, a questionnaire was used to collect data. The questionnaire method is used in expert trials, expert learning Jurisprodential Inquiry (Legal Study). Quantitative data obtained during the study were analyzed using descriptive statistics. Implementation of learning models that have been developed. The validation process is carried out in two steps, namely internal validation and external validation. Internal validation is carried out on the components of the model by using peer review and focus group discussions, while external validation is carried out by testing the use of the model.

\section{RESULTS AND DISCUSSION}

The objectives of the study are: (1) competence Ibadah Fiqh of IAI FIS UNP students in learning at IAI FIS UNP Study Program; and (2) effectiveness of Jurisprodential Inquiry learning model in learning Ibadah Jurisprudence in IAI FIS UNP Study Program.

\section{Overview of Research Locations}

The Jurisprudence Worship was held by the students of IAI FIS UNP in July-December 2019 semester with 16 meetings or face-to-face meetings, plus independent and structured assignments. For this study equipped with the ability of students to solve cases related to Fiqih Worship in accordance with the syllabus of lectures. The syllabus includes:

Tabel 2. Syllabus Content

\begin{tabular}{|c|c|c|}
\hline No & Material & Material Detail \\
\hline 1. & Introduction to Subject & $\begin{array}{l}\text { a. Understanding Worship } \\
\text { b. The Nature and Wisdom Ibadah }\end{array}$ \\
\hline 2. & Thaharah & $\begin{array}{l}\text { a. Thaharah from Hadats } \\
\text { b. Wudu' } \\
\text { c. Mandi (al Ghusl) } \\
\text { d. Tayammum } \\
\text { e. Thaharah from Unclean } \\
\text { f. How to get rid of unclean }\end{array}$ \\
\hline 3. & Prayer & $\begin{array}{ll}\text { a. } & \text { Prerequisite Prayers } \\
\text { b. Walat Prayer Times } \\
\text { c. Terms of Sahabah Prayer } \\
\text { d. How To Do Salat } \\
\text { e. Things that cancel prayer } \\
\text { f. Shalat congregation } \\
\text { g. Sunnah Prayers and Miscellaneous }\end{array}$ \\
\hline
\end{tabular}




\begin{tabular}{ll}
\hline 4. Janazah & a. Bathing the janazah \\
& b. Understanding the body \\
c. Jakat & d. Bury the body \\
a. Zakat concept \\
b. Assets to be Tortured \\
c. Zakat of Gold and Silver \\
d. Zakat of Agricultural Products \\
e. Zakat Rikaz \\
f. Zakat Fitrah \\
g. How to pay Zakat \\
h. That Is Not Entitled to Receive Zakat \\
a. The concept of fasting \\
b. Ramadan fasting \\
c. How to Carry out Fasting \\
d. Sunnah Fasting \\
e. Light Sunnah and Miscellaneous \\
a. The concept of Hajj \\
b. How to perform Hajj \\
c. Ihram \\
d. Hajj & e. Overnight in Muzdalifah \\
& f. f.Take jumrah \\
g. Shave \\
h. h.Tahalluli. \\
i. Overnight at Mina \\
j. Difference between Hajj and Umrah
\end{tabular}

Competence of Fiqh Ibadah of IAI FIS UNP Students in Learning at IAI FIS UNP Study Program.

Pedagogical Competency Indicators

Based on the results of the study, it can be explained that the pedagogical indicators are studied in three sub-indicators namely understanding the theories and concepts of Fiqh Ibadah, understanding methods and evaluating Islamic law cases.The results obtained can be seen in table 3 below.

Table 3. Understanding Theory and Concept of Fiqih Islam

\begin{tabular}{clc}
\hline Questions & Answers & Persentase (\%) \\
\hline 1. & Very Good & 20,00 \\
& Good & 40,00 \\
& Quite Good & 10,66 \\
& Not Good & 29,34 \\
\hline Total & & $100 \%$ \\
\hline
\end{tabular}

Based on table 3 above, it can be seen that the competence of students of IAI FIS UNP in understanding the theory and concept of Worship Piqih as much as $20.00 \%$ is very good, 
$40 \%$ is in the good category and the category is quite good the percentage of $10.66 \%$, and is not good $29,34 \%$. So according to the results of the questionnaire obtained can be explained according to respondents namely students in understanding the theories and concepts of Fiqh of Worship are in good categories.

Table 4. Understanding Jurisprudential Inquiry Methods in Fiqih Ibadah Learning

\begin{tabular}{|c|c|c|}
\hline Questions & Answers & Persentage $(\%)$ \\
\hline \multirow[t]{4}{*}{2.} & Very Good & 19,84 \\
\hline & Good & 67,66 \\
\hline & Quite Good & 9,93 \\
\hline & Not Good & 2,57 \\
\hline Total & & $100 \%$ \\
\hline
\end{tabular}

IAI FIS students with question items covering the concept of Fiqh Ibadah in understanding the methods and evaluations of Islamic law cases. The results of the questionnaire can be seen that the excellent category is $19.84 \%, 67.66 \%$ is good, the category is quite good as much as $9.93 \%$ and the category is not as good as $2.57 \%$. So IAI FIS students in understanding the methods and cases of Islamic law are mostly good category with a percentage of $67.66 \%$.

Table 5. Understanding Islamic Law Cases in Fiqh Ibadah Classes

\begin{tabular}{clc}
\hline \multirow{2}{*}{ Questions } & \multirow{2}{*}{ Answers } & Persentage (\%) \\
\hline \multirow{2}{*}{3.} & Very Good & 15,55 \\
& Good & 61,31 \\
& Quite Good & 15,14 \\
& Not Good & 8,00 \\
\hline Total & & $100 \%$ \\
\hline
\end{tabular}

Based on the table, it can be explained that IAI FIS students in understanding Islamic law cases are in the good category. This can be obtained from the results of the questionnaire percentage obtained as many as $15.55 \%$ who chose very well, $61.31 \%$ who chose good, $15.14 \%$ who chose the category good enough, and 8.00 were not good. These results can be quite clearly seen if calculated with the percentage of good categories more percentage.

Based on the results of interviews conducted with IAI FIS students with the number of questions each written in the answers it can be explained that according to them generally students have understood the concept of Fiqh Ibadah well, so the teaching and learning process went quite well.The JI (Islamic Law Study) learning method used by the Fiqh Ibadah lecturer team with a case approach and conditions of local wisdom varies. These conditions students are active in asking, discussing, and finding solutions to various propositions (Alquran, Hadith, Ijma, Qiyas) in the preaching syllabus of the Fiqh Ibadah.

\section{Professional Competency Indicators}

Percentage results per item answer are for the category of professional competence. The following is an overall summary of the 
questionnaire about the categories of professional abilities with several sub- indicators of mastery of learning material and learning implementation.

Table 6. Learning Assignments in Fiqih Ibadah Course in IAI Study Program FIS UNP

\begin{tabular}{clc}
\hline Questions & Answers & Persentage (\%) \\
\hline 4. & Very Good & 25,84 \\
& Good & 52,04 \\
& Quite Good & 16,12 \\
& Not Good & 07,00 \\
\hline Total & & $100 \%$ \\
\hline
\end{tabular}

From table 6 above it can be explained that respondents who chose very good alternative answers were $25.84 \%$, good answers were $52.04 \%$, and category answers were good enough as much as $16.12 \%$, and not good 07.00 .
Based on these results that the students of IAI FIS in mastering the Fiqh Ibadah learning material are in good category with the percentage of respondents chosen by $93.04 \%$.

Table 7. The Implementation of Jurisprudential Inquiry Learning(Islamic Law Study)

\begin{tabular}{llc}
\hline Questions & Answers & Persentage (\%) \\
\hline 5 & Very Good & 9,26 \\
& Good & 50,31 \\
& Quite Good & 11,33 \\
& Not Good & 31,00 \\
\hline Total & & $100 \%$ \\
\hline
\end{tabular}

Table 7 above is the result of the percentage of questionnaires regarding the implementation of JI (Islamic Law) learning in IAI FIS students. Based on the results of the questionnaire circulated that the good category with a percentage of $50.31 \%$. The results of the study were obtained from the distribution of questionnaires who chose very well as much as $9.26 \%$, good category as much as $50.31 \%$ and those who chose quite well as much as $11.31 \%$.Besides that based on the results of interviews with students about material competence and the application of the JI method it can be explained that teaching materials and learning methods are always enjoyable in discussion, in increasing understanding through cases of Islamic law with the wisdom of Adat Basandi Syara, Syara Basandi Kitabullah in the philosophy of syara that uses customary tattoos.The JI method and casuistic Islamic law are important elements for understanding the Figh Ibadah. In addition, the method is a systematic learning steps in finding a solution to the case, because there is a dialogue between fellow students and looking for the justification in argumentation, then the lecturer explains or rectifies the concept of students who are considered deviant. This is in accordance with the reasons revealed by Azwar (2013), [8].

The Effectiveness of the Jurisprudential Inquiry Learning Model in Learning Fiqh Ibadah

Implementation of Cycle I

In the first cycle, the research findings that were disclosed concerned the planning, 
implementation, observation, and reflection or evaluation of the results of research actions.

Planning

Planning / Preparation:

(2) Preparing the syllabus of the Fiqh Ibadah courses. The syllabus of lectures is distributed to students who take the Fiqh Ibadah courses. Furthermore students are divided into groups to discuss lecture topics.

(3) Prepare various cases for analytical practice for students. Preparation of cases for practice by distributing cases to students prepared by the lecturer. And some will be assigned to students through assigned task groups.

(2) Preparing copies of related teaching materials. Preparation of teaching material chips provided according to the needs of teaching materials, there are also copies copied by students as additional teaching materials in making student group papers

(-) Planning time for action. When the implementation of the action starts from the beginning of the first lecture, so that the first cycle of research is planned to be carried out for 4 lectures. Then proceed the second cycle based on the data of the first cycle in order to achieve success indicators of the quality of lectures.

(-) Compile a series of action activities as a whole. The series of actions compiled are in addition to the preparation of the syllabus, the division of student groups, and a copy of teaching material, as well as preparing a monitoring format for the observer

(2) Develop monitoring techniques at each stage of the study. The format that has been prepared is used by the observer in this case the observer is the lecturer team. Matters monitored in the format are:Phase I Explore Experience; Phase II Brainstorming; Phase III Deepening and Analysis (Understanding of concepts); Phase IV Integrated Synthesis (Applying Concepts in Cooperatives). Besides that, it also conducts field notes on: daily planning, implementation, discussion with observer, analysis of various cases.

Action Implementation

$$
\text { Implementation of Cycle } 1
$$

(2) Before lecturing the activities carried out for the first meeting the lecturer explains the rules of the lecture as stated in the syllabus. Students are asked to prepare lecture material before going on as a group, with the topics listed above. With a number of groups ranging from 3 to 5 people. Besides explaining the assessment system, references, then only at the next meeting will the lecture begin

(®) Lecturers explore student experiences based on what has been prepared beforehand by describing the topics that have been prepared. The lecture topics above are explained by students each time the meeting is based on an agreed group. Then the discussion opens.

(2) Conduct question and answer or discussion so that brainstorming occurs. At this stage skills required to ask questions, the ability to explain answers, detail responses and explain in other ways that require material readiness from students. Lecturers try to make the discussion open to all, there is no monopoly in the conversation, try to really understand the opinions of students, help students who are lost.After a discussion by students, the discussion team (presenter group) conducted an inventory of questions. In order to avoid a monopoly by certain students, each group prepares questions according to the topics discussed.

(2) Conduct deepening or analysis. At this stage the formulation, confirmation of the concept are carried out and then deepened and compared with other concepts, developing the understanding and meaning of the concept. The lecturer explained, asked, elaborated and deepened the conceptualization.The lecturer asks the student again, if the answer is still not right, the lecturer shows the page of the book or the legislation, and the student sees and reads the concept. Then the lecturer clarifies 
the elements of the concept in the context of stabilization. There are also students who record lecturer explanations as the formulation of answers. The lecturer tries to formulate the theoretical foundation that exists with the conditions that occur

Carry out integrated synthesis. At this stage students are expected to experience critical targeting, reflective, cooperative and develop cooperation towards social change. So students are expected to find new ways to process concepts, sharpen the abilities of what they have learned.In this stage the lecturer gives freedom to students expressing in their own language (oral and written), especially in analyzing cases. So students find new formulations for photographing conditions.

Make observations
Conduct an evaluation based on the monitoring format. The aim is to determine the effectiveness, success and obstacles to actions taken by using the Reflective Communication Method, namely the success of:

(อ) passive students in lectures. Most students don't take notes; don't want to ask; students want to answer if appointed; references are not brought during lectures; so there is no interaction with teaching materials; lack of discipline in doing structured tasks; who do group work with just a few people. This was proven during the discussion, only certain students were able to answer and those who were active. Then assessed the ability to analyze various cases of Fiqh Ibadah.

Percentage of cases that can be explained correctly.

End of cycle test results

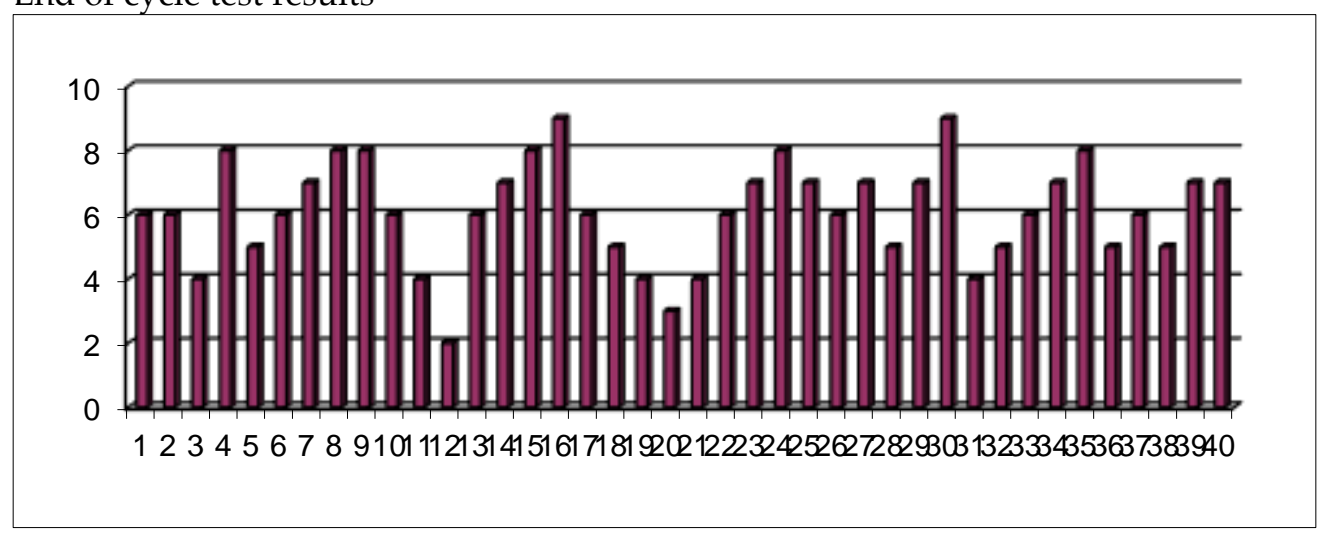

Cases of Islamic law in the Fiqh Ibadah

From the graphic above it can be seen that there is an increase in the learning outcome of those 40 students, and there is also $85 \%$ increase in learning quality of Figh Ibadah and students' activeness in solving cases in learning materials.

\section{CONCLUSIONS}

The conclusions of this research are:

1. IAI FIS UNP Students' competence for Figh Ibadah in the learning process in IAI FIS UNP program has got better under standing in Figh Ibadah theories and concepts which categorized as in good level as well as method and Islamic Law cases.

2. Juriprodential Inquiry Learning Method in Fiqh Ibadah course in IAI FIS UNP program is effective to change the learning result and students' active interest in solving cases given by the lecture. There are some developments of Law Study Models with varied cases based on Minangkabau local wisdom values and students ethnics' origin. 


\section{ACKNOWLEDGMENTS}

The researcher would like to thank to everyone who involved in this research.

\section{REFERENCES}

[1] K. Kereluik, P. Mishra, C. Fahne, and L. Terry. (2014). What Knowledge Is of Most Worth: Teacher Knowledge for 21 St Century Learning Abstract. J. Digit. Learn. Teach. Educ., 29(4), pp. 127-140. doi: 10.1093/acprof:oso/9780195335453. 003.0003 .

[2] Azra (2018). Islam dan Moraliry. UIN Jakarta Press.

[3] A. Moore. (2006). Schooling, Society and Curriculum.Book. doi: 10.4324/9780203 015162.
[4] A. Y. Kolb and D. A. Kolb. (2005). Learning styles and learning spaces: Enhancing experiential learning in higher education," Acad. Manag. Learn. Educ.doi: 10.5465/AMLE.2005.17268566.

[5] Joyce, Bruce. (2017). Models Of Teaching. Pearson. USA

[6] D. Chandler and H. Hwang. (2015). Learning From Learning Theory: A Model of Organizational Adoption Strategies at the Microfoundations of Institutional Theory. J. Manage., 41(5), pp. 1446-1476, 2015, doi: 10.1177/01 49206315572698.

[7] Sugiyono. (2008).Memahami Penelitian Kualitatif Kualitatif Dan $R$ \& D. Bandung: Alfabeta.

[8] J. M. Halstead and M. A. Pike. (2006). Citizenship and Moral Education. p. 199 